\title{
Necrobrasiliana: necropoder e representação indígena em Thiago Martins de Melo
}

\author{
Tiago Hermano Breunig ${ }^{1}$
}

Resumo: Este trabalho consiste em um passeio pelas pinturas da exposição Necrobrasiliana, de Thiago Martins de Melo, destacando as representações dos povos indígenas brasileiros. Interrogamos os sentidos produzidos pela sobreposição de imagens, que sincroniza o terror do passado colonial com o presente, a partir do conceito de necropoder de Achille Mbembe, entre outros autores e conceitos.

Palavras-chave: Thiago Martins de Melo, necropoder, colonialismo, representação

\section{Necrobrasiliana: necropolitics and indigenous representation in Thiago Martins de Melo}

Abstract: This paper consists of a tour through the paintings that integrate the Necrobrasiliana collection, by Thiago Martins de Melo, highlighting the representations of the Brazilian indigenous people in his paintings. Based on Achille Mbembe's concept of necropolitics, we interrogate the meanings produced by the overlap of images, which synchronizes the terror of the colonial past with the present.

Keywords: Thiago Martins de Melo, necropolitics, colonialism, representation

1 Professor Adjunto do Departamento de Letras da Universidade Federal de Pernambuco, UFPE. Tem Bacharelado e Licenciatura em Letras pela Universidade Federal de Santa Catarina, UFSC, Mestrado e Doutorado pelo Programa de Pós-Graduação em Literatura da Universidade Federal de Santa Catarina, UFSC, com período sanduíche na Universidade de Yale. Atua nos grupos de pesquisa DERIVA - Derivações e Representações Interarísticas das Vozes do Atlântico e SUTRA - Subalternidades, Transculturalidade e Perspectivas Decoloniais. Universidade Federal de Pernambuco. E-mail: thbreunig@gmail.com. ORCID: https://orcid.org/0000-0003-3123-3897. Lattes iD: http:// lattes.cnpq.br/4555361609634168. Recife, Brasil 
Em 2019, o artista maranhense Thiago Martins de Melo apresentou a exposição Necrobrasiliana, retratando, com grossas camadas de tinta em telas de grandes proporções, a perpetuação do legado do colonialismo no Brasil e, mais especificamente, a morte e a arbitrariedade com que esta se repete no presente sobre as populações em condições de vulnerabilidade ou subalternidade. O termo "necrobrasiliana", que nomeia a exposição, consiste em um neologismo formado por "necro" (morte) e "brasiliana" (coleção de obras que tematizam o Brasil), o qual se associa ao conceito de necropoder, cunhado pelo intelectual camaronês Achille Mbembe.

Chave para o entendimento da exposição, o colonialismo cria a imagem do Outro, contra a qual a Europa, inicialmente, definiu sua identidade, e posteriormente cinde a sociedade que restou, com suas imagens, do empreendimento colonial, de modo que, pela colonização e escravização, o colonialismo instala a alteridade no interior do mesmo, imaginativamente e, sobretudo, territorialmente, administrativamente, socialmente. Assim, o colonialismo produz uma epistemologia que permanece nas ações colonialistas que, atualmente, satisfazem o progresso do capitalismo, recompondo a geografia imaginativa gerada no seio do etnocentrismo europeu, no nexo, como constata o intelectual palestino Edward W. Said (2007), entre conhecimento e poder que cria o Outro e o oblitera como ser humano. A (re) construção das cenas na obra de Thiago Martins desvela uma metodologia, a repetição, a mesma pela qual, com a contribuição de uma imaginação que justifica a exploração colonial, o colonialismo se impõe ao outro, ao dominar territorialmente a terra e, posteriormente, a cindir racial e socialmente, gerando novas distribuições territoriais no ambiente colonizado.

Para tanto, o artista trabalha com imagens que partem desde a iconografia colonial (xilogravuras e gravuras em metal que ilustram os textos dos chamados cronistas do descobrimento), a fotografias recentes, bem como reproduz as colunas de uma instalação de sua autoria, de 2014 , que retrata a paisagem da periferia do capitalismo internacional, caracterizada pela economia de exploração, inaugurada aqui com a colonização portuguesa. As colunas reaparecem em praticamente todas as telas do conjunto de obras, mais do que como um elemento da contemporaneidade e de unidade entre as telas da coleção, mas como os pilares basilares da nação brasileira, ou seja, como representação do que sustenta o poder de morte no Brasil ao longo de todo um tempo que se inicia com a colonização. Thiago Martins procura compreender, portanto, como aquelas imagens corroboraram um ideal colonial, construindo uma imagem do Brasil. E, ao sobrepor imagens recentes a imagens do Brasil colonial, o artista permite perceber a perpetuação da morte instaurada pelo processo colonial. 
Assim, se a nação constitui, como afirma a crítica literária brasileira Leyla Perrone-Moisés (2007, p. 33), "um conjunto de imagens", a coleção de obras de Necrobrasiliana reconstitui criticamente o conjunto de imagens que conforma a nação brasileira, revisando a construção de uma narrativa visual de mais de 500 anos. Passeemos pela exposição para observar, ainda que breve e provisoriamente, como o passado se conjuga com o presente nas telas que compõem o conjunto que Thiago Martins denomina Necrobrasiliana, e que se caracteriza pela colagem de imagens. Procuraremos, inicialmente, identificar algumas das imagens que compõem as telas para, a seguir, propor uma leitura dos sentidos produzidos pela sua sobreposição, com o amparo das teorias evocadas pelo conceito proposto por Mbembe.

Figura 1

Thiago Martins de Melo. Invasão de demônios a Pindorama, após Jean de Léry, Joãozinho Trinta, Tuiutíe Mangueira, 2019. Óleo sobre tela, $260 \times 360 \mathrm{~cm}$. Foto: Bruno Leão
A tela Invasão dos demônios a Pindorama, após Jean de Léry, Joãozinho Trinta, Tuiuti e Mangueira, apresenta uma gravura de Theodore de Bry, O demônio Aygnan atormenta os selvagens, que ilustra Histoire d'un Voyage faict en la terre du Brésil, de Jean de Léry, de 1578. O demônio Aygnan, segundo informa Jean de Léry (1880, p. 106), simboliza um espírito maligno que espanta e atormenta os tupinambás. A ilustração, que representa europeus cristãos procurando converter os nativos, simboliza, aqui, o tormento da colonização portuguesa. A "invasão de Pindorama" consiste, nesse sentido, em uma alteração da perspectiva da chamada "descoberta do Brasil",

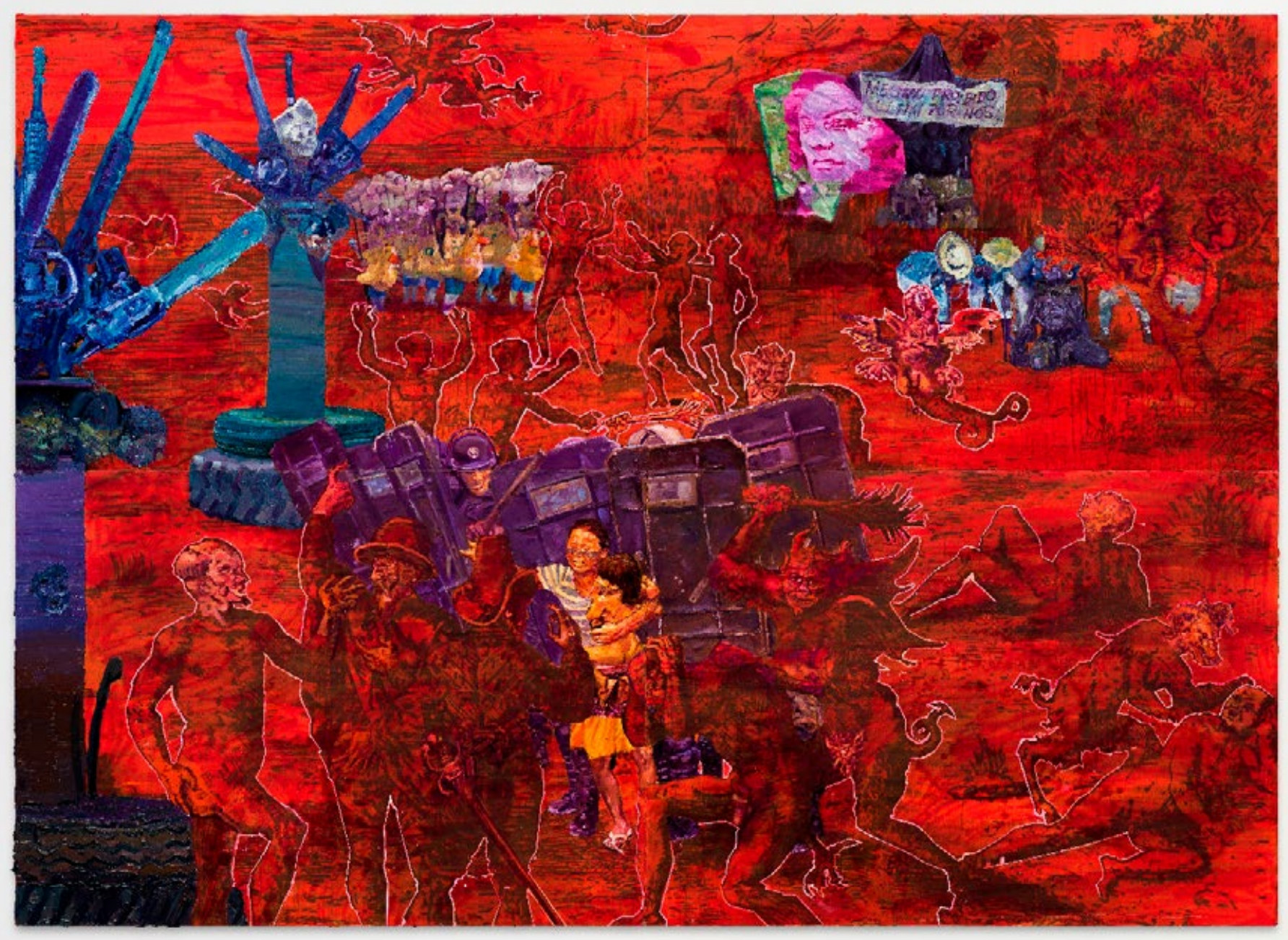


de modo que o "após", que intitula a obra, significa o aspecto permanente da invasão que se revela, assim, presente nos eventos reproduzidos na tela, separados por centenas de anos.

Figura 2 O demônio Aygnan atormenta os selvagens. Gravura em metal. America, pt. 3, de Theodor de Bry, de 1592. Fonte: https://jcb.lunaimaging.com

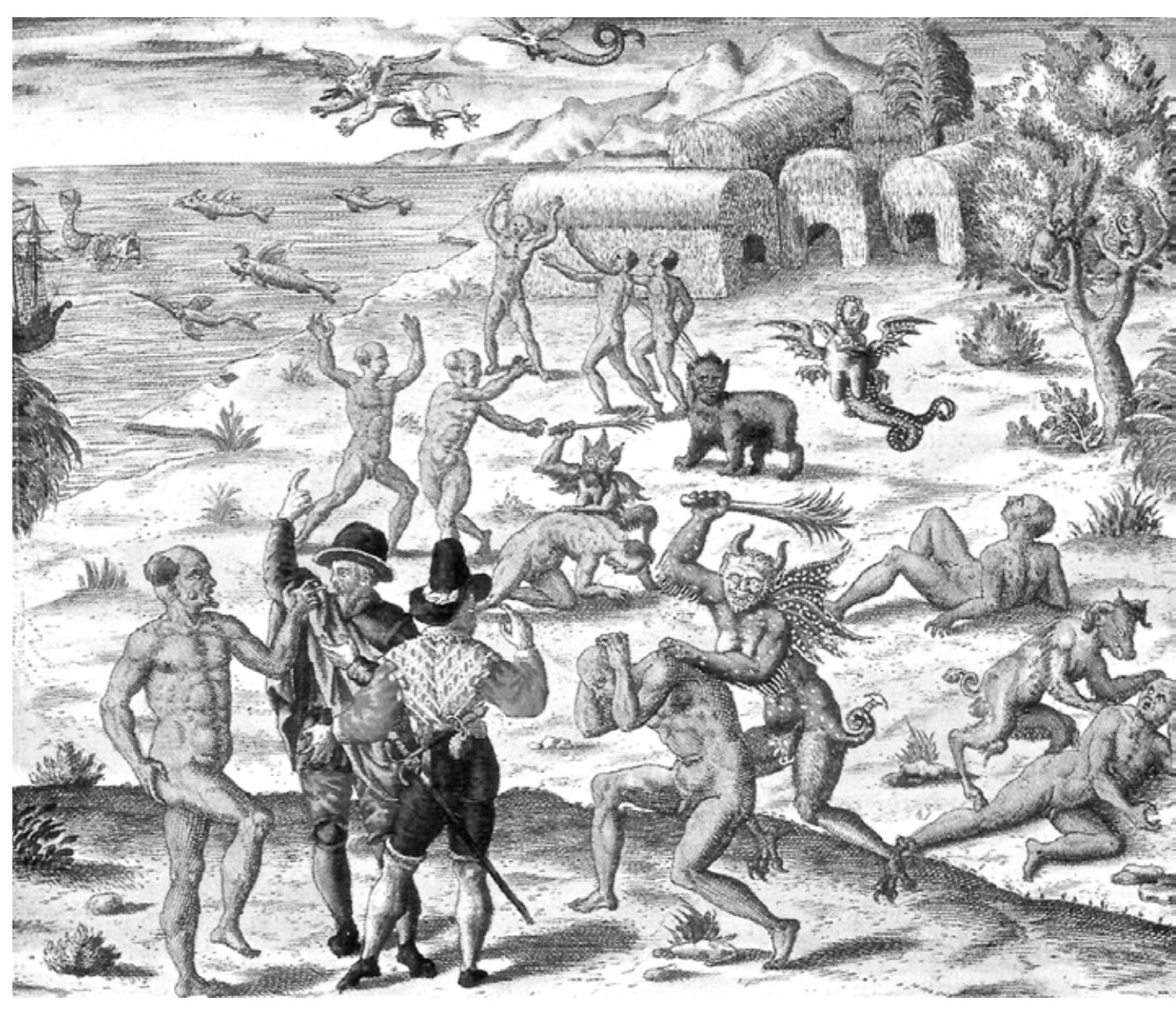

Na tela, a ilustração de Theodore de Bry aparece fundida a uma imagem de reintegração de posse em que a polícia expulsa os índios de suas terras no Amazonas em 2008: a mesma imagem, o mesmo gesto, em que o cassetete da polícia parece mimetizar o bastão do demônio Aygnan, e a polícia, o próprio demônio Aygnan. Compõem ainda a cena do tormento da colonização as alegorias de carnaval de "Joãozinho Trinta, Tuiti e Mangueira", que, aqui, alegorizam criticamente a perpetuação do evento da invasão: o enredo da Beija-Flor, de 1989, do Paraíso do Tuiuti, de 2018, com o enredo "Meu Deus, meu Deus, está extinta a escravidão?" e, finalmente, da Mangueira, de 2019.

A tela Escadaria do decapitado, por sua vez, apresenta, ao centro, a reprodução da fotografia, de julho de 1938, da exposição das cabeças de Lampião, 
Figura 3

Thiago Martins de Melo. Escadaria do decapitado, 2019

Óleo sobre tela, $320 \times 240 \mathrm{~cm}$

Foto: Bruno Leão

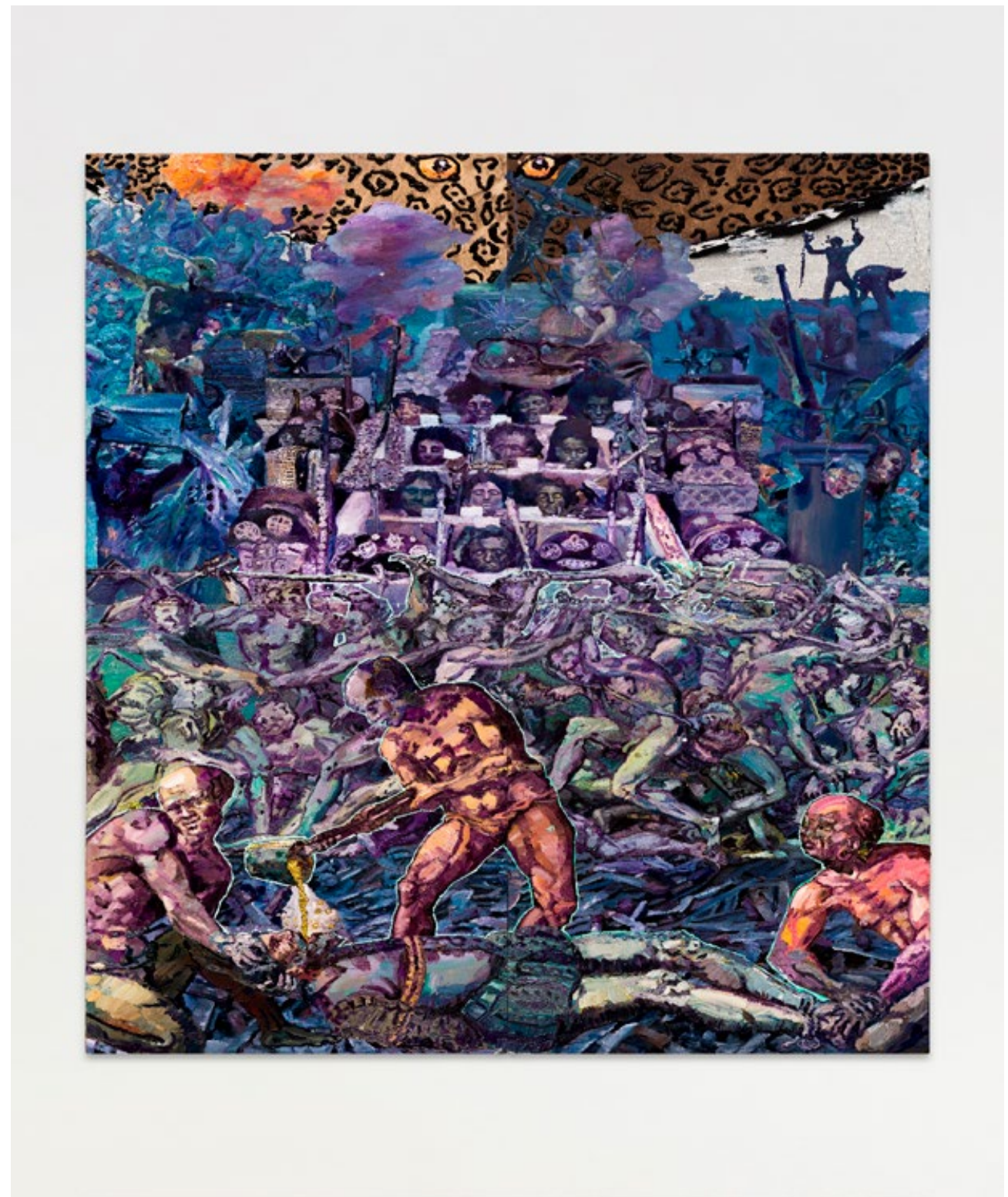

Maria Bonita e outros integrantes do cangaço, em uma escadaria, e sob ela outra ilustração de Theodore de Bry, publicada em America, nos anos 1590.

A decapitação constitui um motivo recorrente na obra de Thiago Martins, simbolizando tanto a destituição da terra, a que a cabeça se liga pelo corpo, quanto a destituição de uma razão outra que resiste martirizadamente ao poder, que decepa cabeças simbolicamente e literalmente. Nesse sentido, a ilustração de Theodore de Bry representa índios imolando um colonizador espanhol sedento de ouro, despejando ouro líquido em sua garganta. E sobreposta a ela, entre outras imagens, a ilustração Combate de homens nus, de Etienne Delaune, ilustra índios tupinambás, como sugere a presença do Enduap, que, como descreve Hans Staden (1930, p. 149), é um 
Figura 4

Por causa da sede dos espanhóis por ouro, índios despejam ouro líquido neles. Gravura em metal. America, pt. 4, de Theodor de Bry, de 1594. Fonte: https://dcc. newberry.org

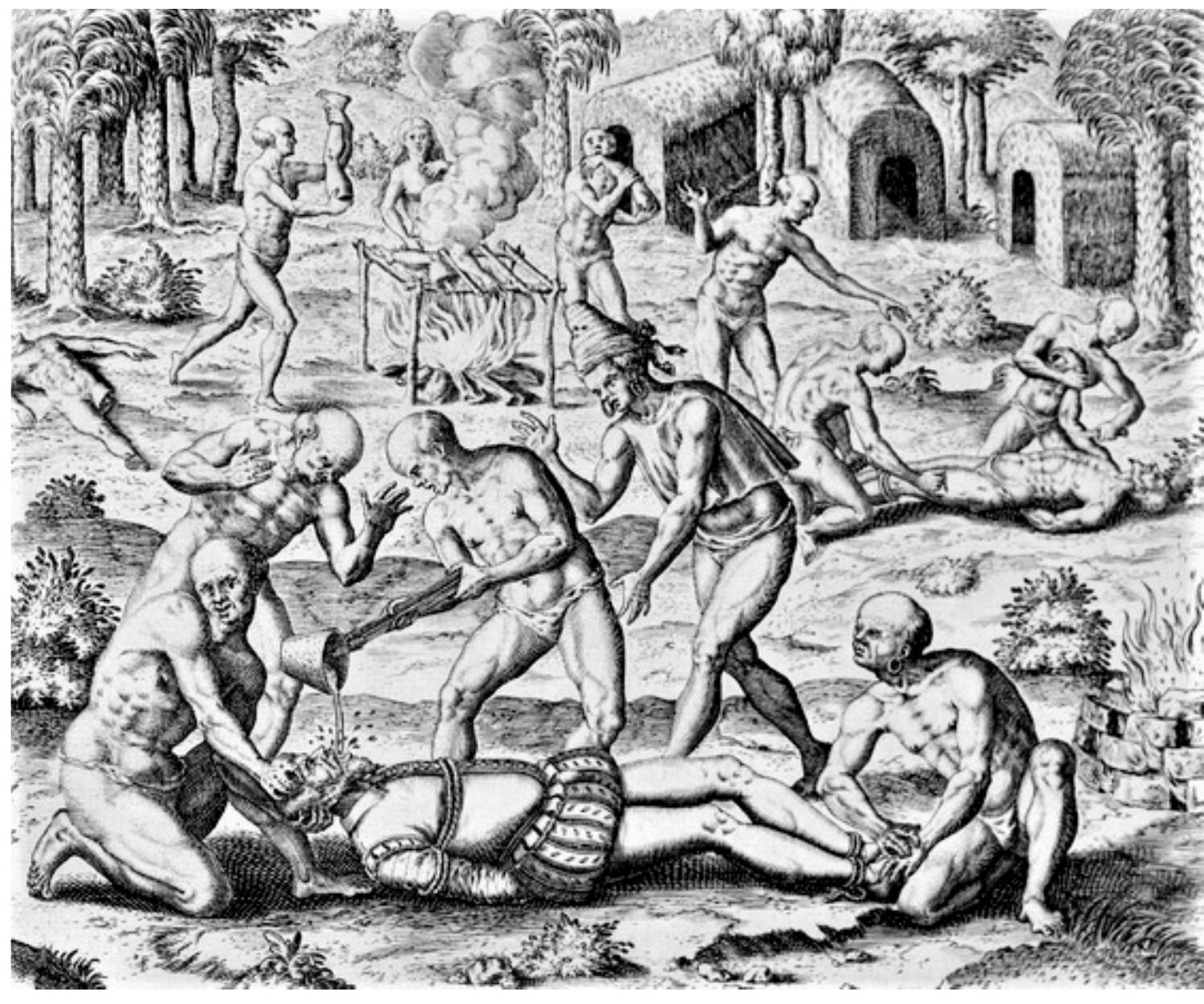

"enfeite de penas de avestruz, enfeite grande e redondo, que amarram na parte de trás, quando vão à guerra contra seus inimigos, ou fazem alguma festa. Chama-se Enduap", explica Staden acerca dos tupinambás.

Figura 5

Enduap. Fonte: STADEN, 1930, p.

149.

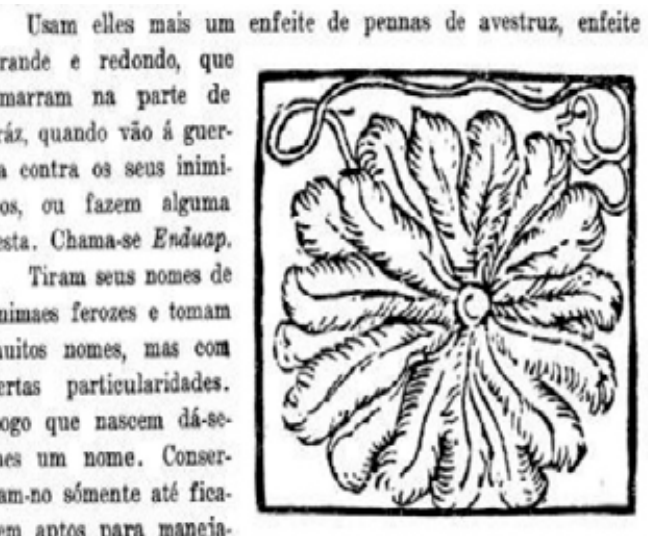
remi aptos para maneja-

rem armas e matarem inimigos. A quantos depois matam, outros tantos nomes tomam. grande e redondo, que amarram na parte de tráx, quando vão á guerra contra os seus inimigos, ou fazem alguma festa. Chama-se Enduop, animas muitos nomes, mas cons certas particularidades. Logo que nascem dá-selhes um nome. Conser-
} tantes nowes tomser 
Figura 6 Dança dos tupinambás. Gravura em metal. America, pt. 3, de Theodor de Bry, de 1592. Fonte: https://jcb.lunaimaging.com

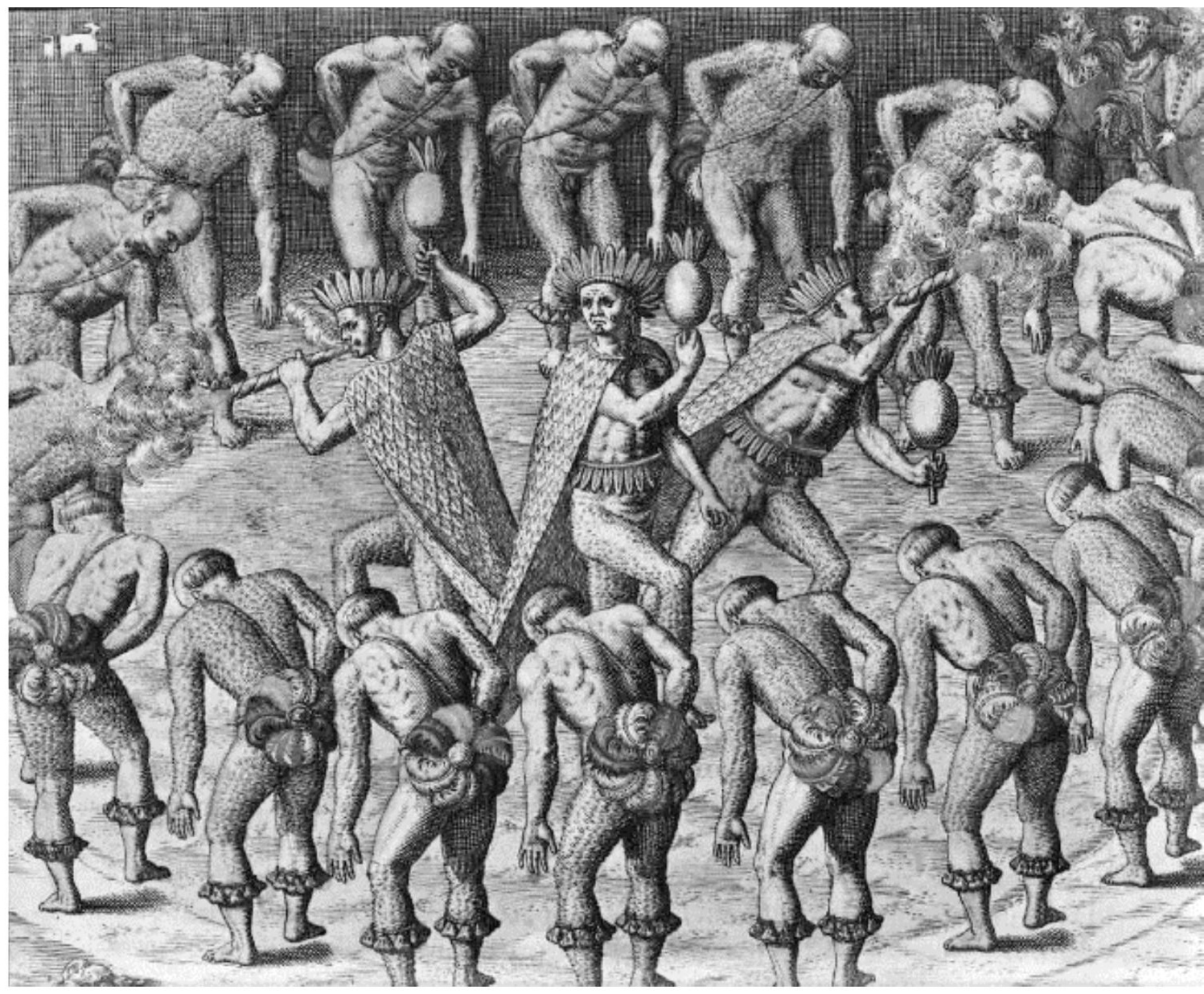

Em Tempo e sol de Luzia, observarmos a ilustração Dança dos Tupinambás, de Theodore de Bry, de 1592, que representa um ritual, com três pajés no centro, observados por três colonizadores europeus:

No centro da tela se encontra "a primeira brasileira", Luzia, o fóssil humano mais antigo encontrado na América do Sul, o qual se funde a um exemplar da arte pré-cabralina ou, mais especificamente, da cultura Tapajônica, um vaso com motivos zoomorfos produzido por índios tapajós, cuja cultura se extinguiu com a colonização portuguesa. Luzia aqui, separada de seu corpo, constitui a representação dos povos nativos, bem como de sua destituição de sua terra, de sua razão e de sua cultura. Acima dela, fundida a um indígena que toca uma flauta utilizada em rituais de vida e morte, observamos a constelação da anta do norte, uma constelação indígena que representa uma anta que caminha pela Via Láctea que, por sua vez, é o Caminho das Antas. A constelação da anta do norte corresponde à primavera, e surge, para os povos indígenas do norte, em setembro, mesmo mês em que o Museu Nacional do Brasil, que guardava Luzia, foi incendiado, em 2018. 
Figura 7

Thiago Martins de Melo. Tempo e sol de Luzia, 2019.

Óleo sobre tela, $240 \times 160 \mathrm{~cm}$. Foto: Bruno Leão

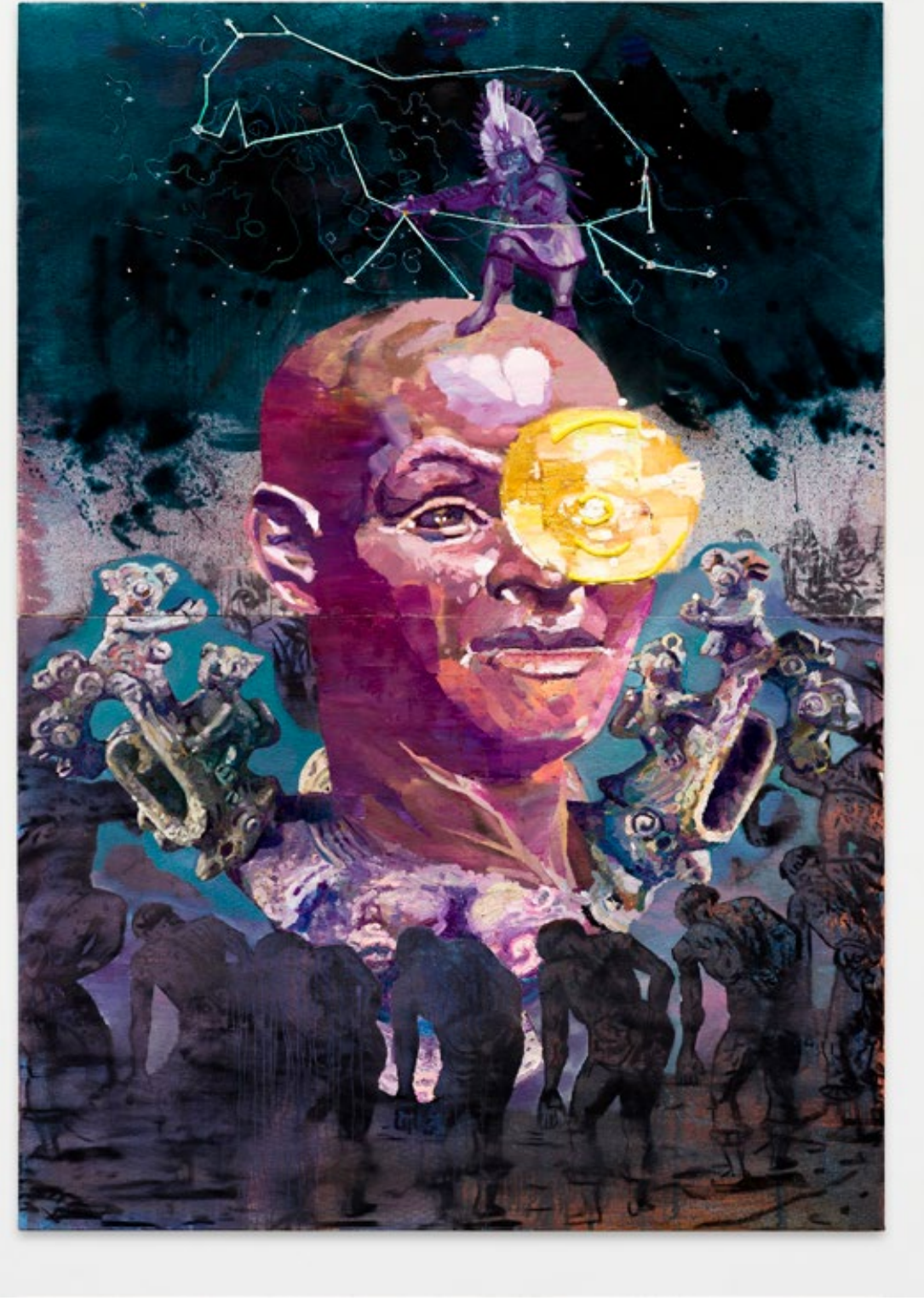

No trabalho de Thiago Martins, portanto, a composição conforma uma acumulação de imagens dispersas no tempo desde a colonização do Brasil, geralmente relacionadas com o terror enfrentado pelas populações em situação de vulnerabilidade ou subalternidade. $O$ artista promove o encontro das imagens do passado e do presente de modo a apagar o distanciamento temporal e moral que protege o presente no interior de um discurso legitimador que, finalmente, revela sua familiaridade com o passado, a sua contemporaneidade. Apreendida na tela como uma temporalidade compreendida como presente permanente, a sincronicidade das imagens, retiradas de sua suposta sequencialidade, revela, por fim, sob o aparente 


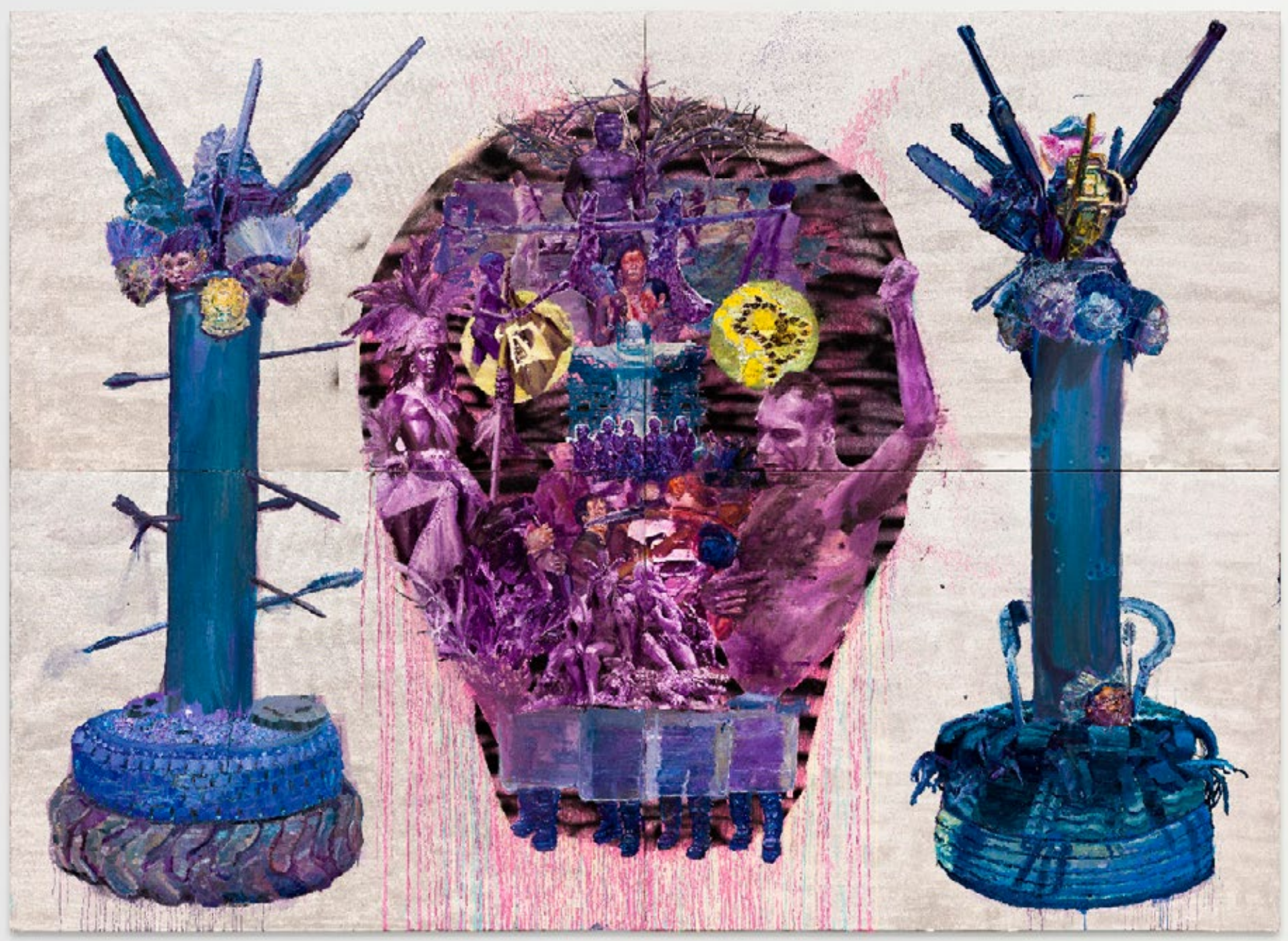

Figura 8 Thiago Martins de Melo. Necrobrasiliana, 2019. Óleo sobre tela, 260 x $360 \mathrm{~cm}$. Foto: Bruno Leão movimento do tempo, que algo permanece estaticamente se repetindo. Os quadros compõem, assim, a narrativa silenciosa da estaticidade do terror colonial, um tempo parado, a despeito do suposto progresso da civilização ocidental.

A perpetuação da morte, evidenciada pela sobreposição de imagens nas telas de Thiago Martins, bem como a reação das populações subalternas diante do poder de morte, resume a obra que intitula a exposição:

Em Necrobrasiliana, a partir dos pés de um pelotão de choque da polícia militar, emerge, em forma de caveira, um amontoado de imagens, com destaque para as populações indígenas brasileiras, que desde a colonização resistem ao poder. A caveira se situa entre duas colunas ou totens de armas e serras com cabeças decepadas de índios, que reproduzem esculturas do artista que aparecem repetidamente nas telas da exposição, simbolizando as bases do processo colonial brasileiro, fundamentado na escravização e na exploração da terra. Entre as imagens que conformam a caveira, vemos a reação da Kaiapó Tuíra, em uma reunião em Altamira, no Pará, em 1989, 
com o terçado no rosto de um representante da Eletronorte, em protesto contra a construção de barragens no Xingu. Afinal, se no mundo colonial "o indígena é um ser encurralado", como nota Frantz Fanon (1968, p. 39), ele sempre pode se insurgir como o "grande organismo surgido como reação à violência primordial do colonialista", pois compreende que "a vida é um combate sem fim" (FANON, 1968, p. 73).

O termo que nomeia a tela e a exposição indica, de certa forma, o procedimento composicional do artista, que compõe camadas formadas por imagens apropriadas antropofagicamente, e se trata, como vimos, de um neologismo ao qual se associam os conceitos de necropoder e necropolítica, aludidos em outra obra da exposição: Aquele que é digno de ser morto/ Aquele que é digno de estar vivo (tributo a I-Juca Pirama):

Figura 9

Thiago Martins de Melo. Aquele que é digno de ser morto/aquele que é digno de estar vivo (tributo a I- Juca-Pirama), 2019. Óleo sobre tela, $360 \times 260 \mathrm{~cm}$. Foto: Bruno Leão

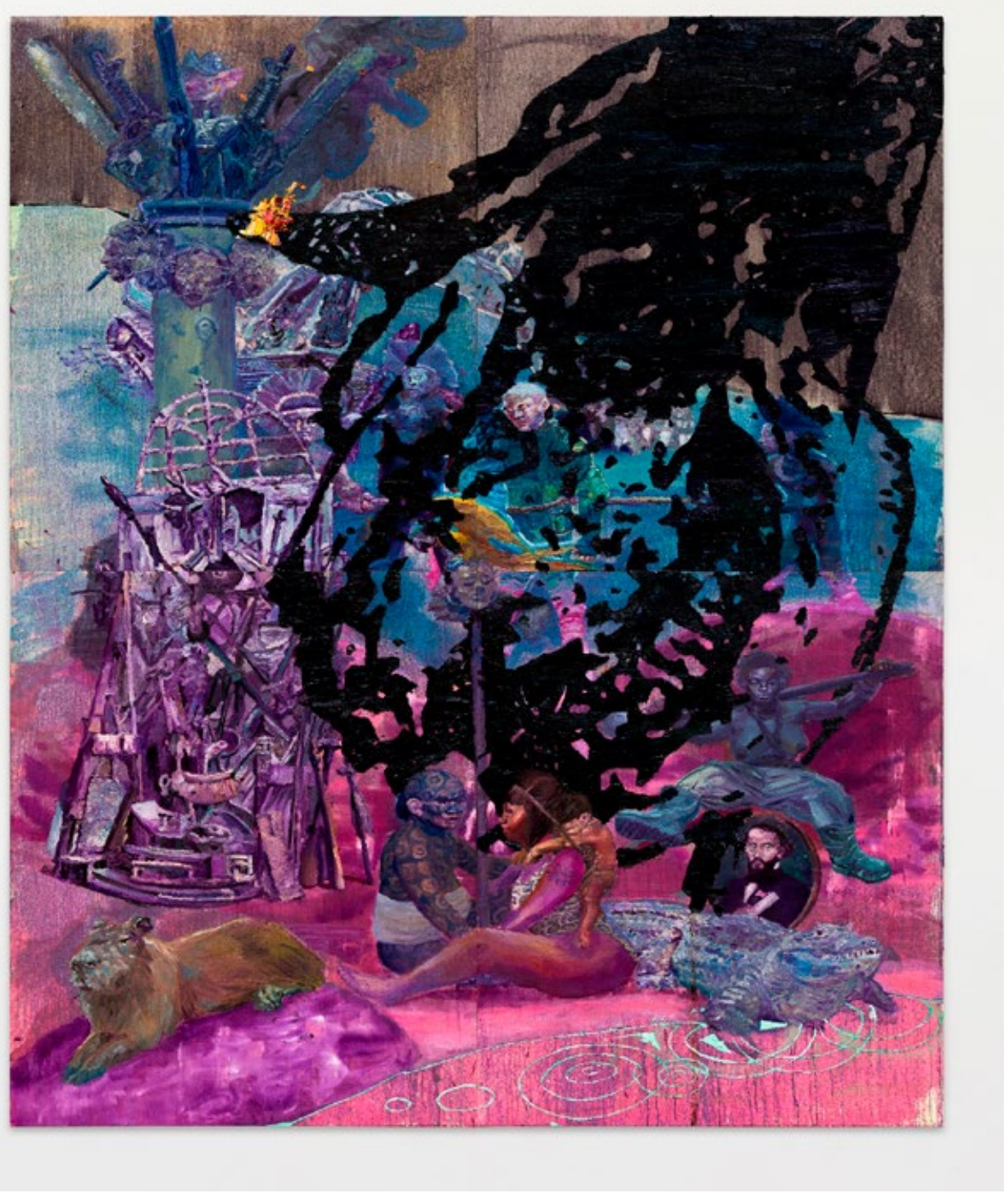


Nela, em meio a uma sobreposição de imagens, em que predominam índios, figura o poeta indianista autor de I-Juca Pirama, Gonçalves Dias, tal como retratado por Édouard Viénot. As sobreposições de imagens, aqui como em toda a coleção, retratam o terror colonial e seus desdobramentos atuais. Elas produzem uma sincronia entre passado e presente que permite compreender, com o devido distanciamento temporal, o terror do presente a partir de imagens do passado, e perceber como o passado não cessa de passar. Condensando, em fragmentos, a longa narrativa do colonialismo e de seu legado, as sobreposições de imagens deixam entrever a sincronicidade do presente com um passado aparentemente remoto, que, no entanto, emerge incessantemente na contemporaneidade, onde, teoricamente, não teria lugar.

O efeito da sobreposição de imagens do passado e do presente, como sugerimos, consiste em perceber a falta de movimento efetivo no tempo, considerando o movimento como o rompimento da estaticidade das condições representadas. A percepção da imobilidade mobiliza, sem contradição, o pensamento no entendimento do nosso tempo, sem remissão nem redenção do passado ou do presente, ligados na obra de Thiago Martins por violentas pinceladas de tinta que escorre, na tela, como sangue, com cores que parecem gritar. $\mathrm{O}$ artista captura crimes contra a humanidade. Assim, entrevemos, em meio a imagens da iconografia colonial, os rostos e os corpos de Marighella e Marielle Franco, por exemplo, ilustrando a necropolítica praticada no Brasil.

Proponente do conceito de necropolítica, Achille Mbembe retoma e aprofunda os conceitos de biopoder e biopolítica, de Michel Foucault, os quais considera insuficientes para "explicar as formas contemporâneas de subjugação da vida ao poder da morte" (MBEMBE, 2016, p. 146). Assim, o intelectual camaronês propõe as noções de necropoder e necropolítica para interrogar o direito de matar e compreender a inscrição da vida, da morte e do corpo humano na ordem do poder. Mbembe (2016, p. 123) entende "que a expressão máxima da soberania reside, em grande medida, no poder e na capacidade de ditar quem pode viver e quem deve morrer", razão pela qual "matar ou deixar viver constituem os limites da soberania, seus atributos fundamentais". O intelectual camaronês conclui que "a soberania é exercer controle sobre a mortalidade e definir a vida como a implantação e manifestação de poder" (MBEMBE, 2016, p. 123). E que, em configurações de "ocupação colonial", em que "a exceção proporciona a estrutura da soberania", esta se revela como "a capacidade de definir quem importa e quem não importa, quem é 'descartável' e quem não é" (MBEMBE, 2016, p. 135). 
A preocupação de Mbembe, ao inquirir a relação entre razão e modernidade, concentra-se nas formas de soberania cujo projeto consiste na "instrumentalização generalizada da existência humana" e na "'destruição material de corpos humanos e populações'” (MBEMBE, 2016, p. 125). Para tanto, ele retoma ainda o conceito de estado de exceção, do intelectual italiano Giorgio Agamben, propondo um paralelo entre a colonização e o estado de exceção, ou seja, o dispositivo tornado paradigma de governo que, pela suspensão indeterminada da lei, constitui, como explica Agamben (2004, p. 13), um "patamar de indeterminação entre democracia e absolutismo" ou "a forma legal daquilo que não pode ter forma legal" (AGAMBEN, 2004, p. 12). O estado de exceção, deixando de ser excepcional, tornou-se padrão de atuação dos governos para legitimação da suspensão dos direitos, conforme antecipava Walter Benjamin (1994, p. 226) ao constatar que a "tradição dos oprimidos nos ensina que o 'estado de exceção' em que vivemos é na verdade a regra geral".

Mbembe (2016, p. 133) observa que "as colônias são semelhantes às fronteiras. Elas são habitadas por 'selvagens '. As colônias não são organizadas de forma estatal e não criaram um mundo humano". E conclui que "as colônias são o local por excelência em que os controles e as garantias de ordem judicial podem ser suspensos - a zona em que a violência do estado de exceção supostamente opera a serviço da 'civilização'": "a colônia representa o lugar em que a soberania consiste fundamentalmente no exercício de um poder à margem da lei (ab legibus solutus) e no qual tipicamente a 'paz' assume a face de uma 'guerra sem fim'" (MBEMBE, 2016, p. 132). E por essa razão, Mbembe (2016, p. 130) postula que

\footnotetext{
Qualquer relato histórico do surgimento do terror moderno precisa tratar da escravidão, que pode ser considerada uma das primeiras instâncias da experimentação biopolítica. Em muitos aspectos, a própria estrutura do sistema de colonização e suas consequências manifesta a figura emblemática e paradoxal do estado de exceção.
}

Ao conjugar soberania e biopolítica, analisadas a partir do processo colonial ou, mais precisamente, do imperialismo português, o professor de Literatura Portuguesa e Brasileira da Universidade de Bolonha, Roberto Vecchi (2007, p. 181), assim como Mbembe, identifica a colônia com o campo ou o estado de exceção, concluindo que "no âmbito colonial o papel duma proteção negativa da vida é bastante evidente a partir da recodificação política, de um nomos, da vida ou das diferentes tipologias de vida". Chegando a conclusões semelhantes às de Mbembe, Vecchi assinala que: 
A configuração do xadrez conjugando soberania, biopolítica declinadas pelas temporalidades do moderno, torna também mais legível uma revisão histórico-conceptual do imperialismo português cujas raízes profundas tornam a questão mais complexa e refinada pela instrumentação jurídica representativa que se deve mobilizar. Também por esse viés, como veremos, o imperialismo português se articula como biopolítico e moderno em virtude, poder-se-ia dizer, duma precocidade empírica. As causas são múltiplas e dizem respeito tanto às condições históricas do expansionismo português como às adequações conceptuais da soberania na rede de anomalias desse contexto. Se Foucault aponta para a transformação dos estados territoriais em estados de população como momento de variação dos princípios de soberania e de introdução duma cesura biológica fundamental, diferenciando o âmbito, que ocorreria por volta do séc. XVIII, seria interessante deter-se sobre as condições históricas que tornaram essa subdivisão empírica entre povo e população constitutiva de um colonialismo, como o português, promovido por uma pequena nação periférica dentro dum espaço imperial de dimensões planetárias. É imediato que a assimetria entre o corpo político da nação e o corpo biológico do império introduz logo um divisor funcionando já (ainda que não conceptualmente) como biopolítico (VECCHI, 2007, p. 181).

Para Vecchi (2007), as colônias funcionam, do ponto de vista do direito coIonial, como espaços permanentes de exceção, em que a separação da vida nua produz o espaço biológico do campo. Afinal, as colônias antecipam as divisões funcionais que caracterizam a biopolítica moderna, promovendo, pela cesura biológica e desqualificação da vida e da morte, a subdivisão, constitutiva do colonialismo, entre, de um lado, povo, corpo político da nação ou bíos, e, de outro, população, corpo biológico do império ou zoé.

Para tanto, a "modernidade" do colonialismo português e de suas práticas imunitárias se caracteriza, segundo Vecchi, por um duplo movimento: de desterritorialização do corpo político, soberano da nação, e de imediata reterritorialização simbólica do novo corpo biológico, de reinscrição do exterior no interior. Vecchi conclui que esse duplo movimento gera uma tensão entre as categorias que estão na base da biopolítica moderna, de modo que, podemos inferir, as relações entre colonizado e colonizador, colônia e metrópole se atualizam na organização e distribuição, inclusive territorialmente ou espacialmente, das populações socialmente vulnerabilizadas desde a colonização e o projeto biológico da política colonial que conforma, segundo o professor italiano, o caráter biopolítico do colonialismo.

Mas a relação entre a vida e a morte, o "poder de 'fazer' viver e de 'deixar' morrer" que, para Foucault (2005, p. 287), define a biopolítica moderna, essa relação que, para Mbembe, funda a noção de soberania, enquanto capacidade de definir quem deve viver e quem deve morrer, Thiago Martins a encontra no personagem do poema de Gonçalves Dias. Afinal, l-Juca Pirama pode ser traduzido do tupi como "aquele que deve ser morto", e nomeia um guerreiro tupi que, aprisionado por uma tribo timbira, escapa ao ritual de morte clamando pela vida em razão do pai cego: 
Meu canto de morte,

Guerreiros, ouvi:

Sou filho das selvas,

Nas selvas cresci;

Guerreiros, descendo

Da tribo tupi.

(DIAS, 2008, p. 1137)

Liberto pelo chefe da tribo Timbira, I-Juca Pirama promete retornar para honrar o ritual de antropofagia, sendo, no entanto, considerado indigno da morte ritual, uma condição, justamente, do homo sacer, a condição, como explica Agamben (2002, p. 91), de uma vida "matável e insacrificável":

- Não voltes!

É bem feliz, se existe, em que não veja,

Que filho tem, qual chora: és livre; parte!

(DIAS, 2008, p. 1141)

afirma o chefe da tribo, que, a seguir, justifica a negação em razão da lógica antropofágica:

\footnotetext{
- Mentiste, que um Tupi não chora nunca,

E tu choraste!... parte; não queremos

Com carne vil enfraquecer os fortes
}

(DIAS, 2008, p. 1141).

Os rituais antropófagos aparecem, com certa obsessão, nas primeiras representações dos povos indígenas brasileiros. A exemplo da xilogravura abaixo, que supostamente é a primeira reprodução europeia de indígenas brasileiros, publicada na Alemanha, em 1504, e que mostra tupinambás antropófagos se alimentando de carne humana, e ao fundo os navios dos colonizadores portugueses se aproximando.

A cena é similar à xilogravura abaixo do livro de Hans Staden, intitulado História Verdadeira e Descrição de uma Terra de Selvagens, Nus e Cruéis Comedores de Seres Humanos, Situada no Novo Mundo da América, Desconhecida antes e depois de Jesus Cristo nas Terras de Hessen até os Dois Últimos Anos, Visto que Hans Staden, de Homberg, em Hessen, a Conheceu por Experiência Própria e agora a Traz a Público com essa Impressão, também conhecido como Viagem ao Brasil, publicado em Marburgo, na Alemanha, em 1557. 
Figura 10

Xilogravura de

Johann Fros-

chauer para ilus-

trar a primeira

edição da carta

Mundus Novus

publicada em Au-

gsburgo em 1504

Fonte: BUENO

2016, p. 45.

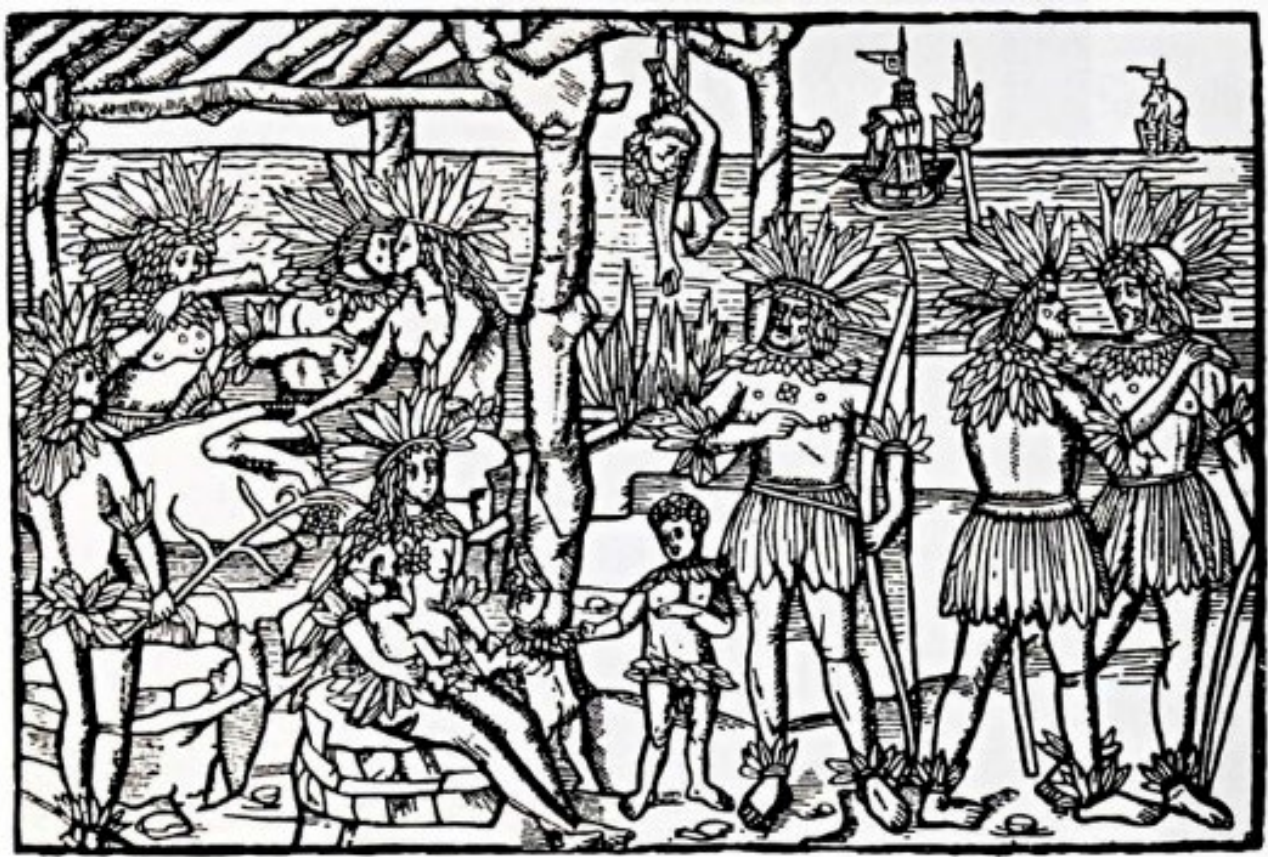

Figura 11

Xilogravura de

Johann Fros-

chauer para ilus-

trar a primeira

edição da carta

Mundus Novus,

publicada em Au-

gsburgo em 1504

Fonte: BUENO,

2016, p. 45.

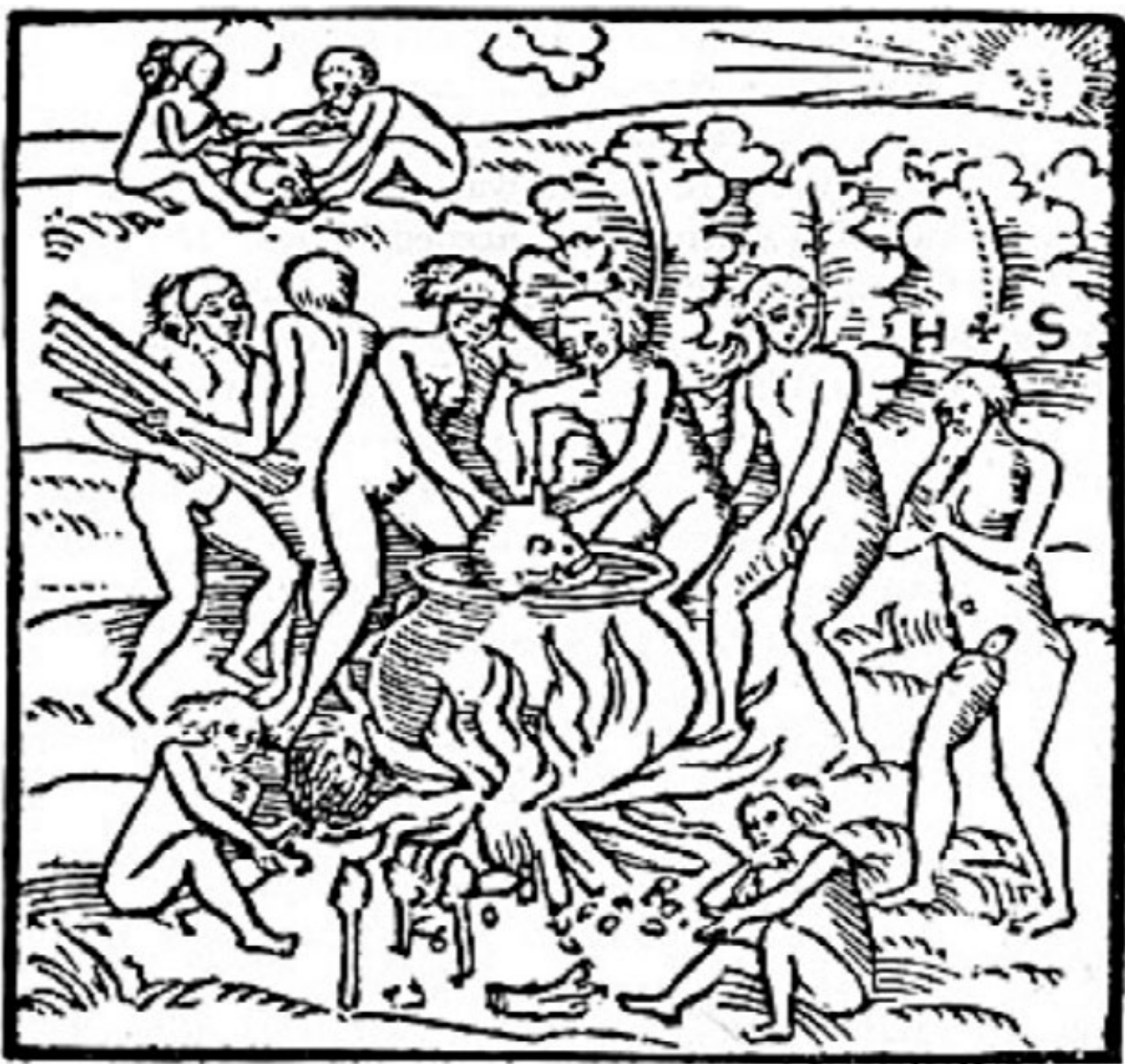


Qual a razão dessa obsessão com a "Descrição de uma Terra de Selvagens, Nus e Cruéis Comedores de Seres Humanos, Situada no Novo Mundo", para falar com Hans Staden? Trata-se, evidentemente, de representar os povos nativos como figuras bestiais, como ilustra um mapa de 1558, elaborado pelo cartógrafo real Diogo Homem:

Figura 12

Detalhe do mapa de Diogo Homem, presente em Atlas de Diogo Homem, de 1558.Fonte: SOUTO, 2017, p. 823.

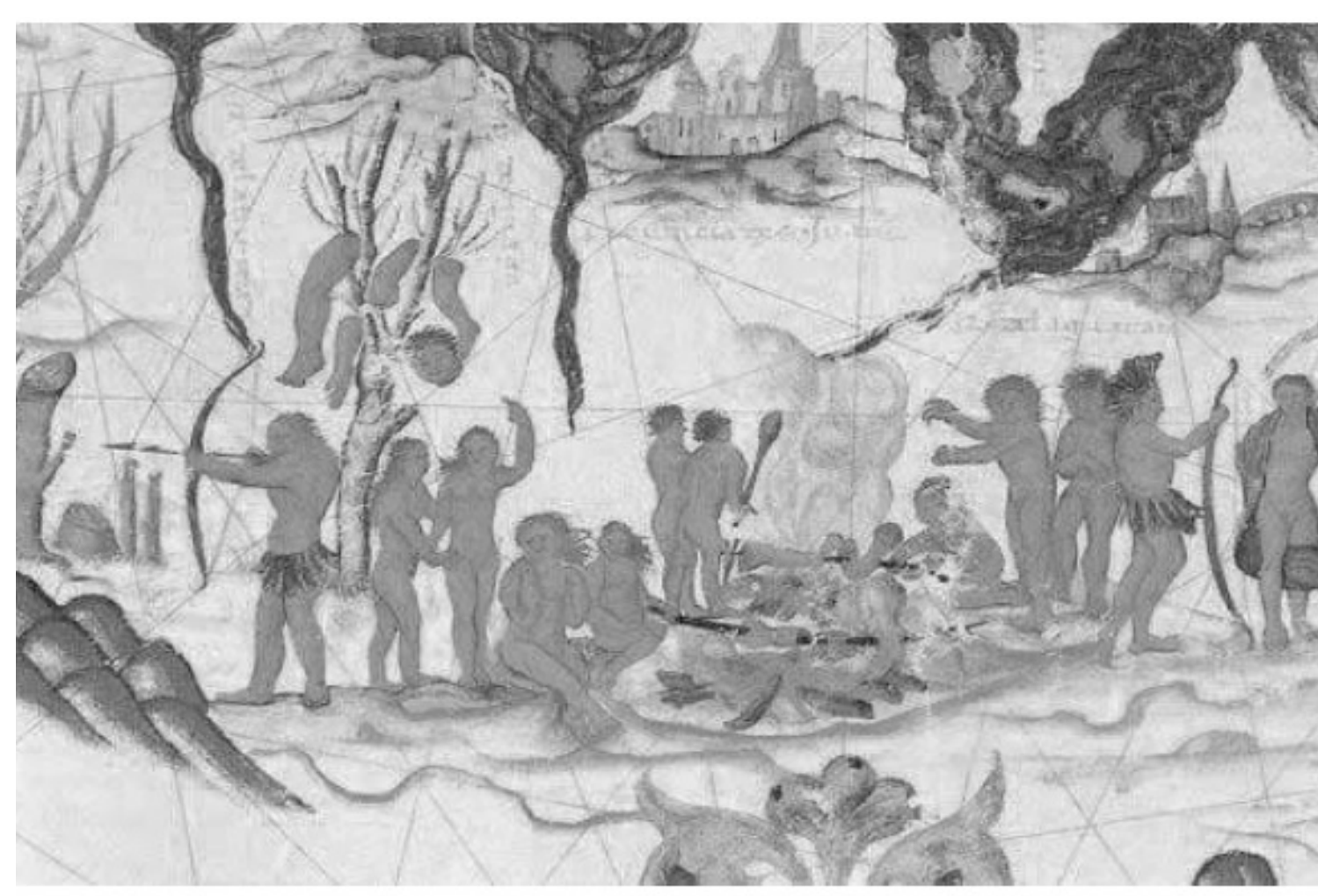

O mapa representa povos indígenas no estreito de Magalhães como gigantes monstruosos, "comedores de seres humanos", como diria Hans Staden, que a colonização supostamente deveria salvar, pela conversão ao cristianismo, e civilizar, para o que o mapa não apenas indica o caminho, como demarca aquelas fronteiras "habitadas por 'selvagens', sem organização estatal e humana, de que fala Mbembe (2016, p. 133). As colônias, com efeito, são essas fronteiras, são o local por excelência em que "a violência do estado de exceção supostamente opera a serviço da 'civilização'" (MBEMBE, 2016, p. 132), e que, funcionando como espaços permanentes de exceção, antecipam, como constata Vecchi (2007), as divisões funcionais que caracterizam a biopolítica moderna. São essas fronteiras que separam "quem pode viver e quem deve morrer", ou "Aquele que é digno de ser morto" e "Aquele que é digno de estar vivo", para falar com Thiago Martins. Em suas telas, as linhas que demarcam a geografia imaginativa, caracterizada pela divisão que, associada a atividades expansivas, produz 
separações territoriais, nacionais e raciais, parecem se fundir confundindo a classificação que opera na qualificação do outro, de modo a desestabilizar as convicções produzidas pelas narrativas coloniais. Thiago Martins retoma criticamente a "ampla reserva de imaginários culturais", como designaria Mbembe (2016, p. 135), produzida pela territorialização do colonialismo, que inscreve um novo conjunto de relações sociais e espaciais, apreendidas nas telas.

Mbembe, ao interrogar a relação entre necropoder e ocupação colonial, articula justamente a territorialização enquanto inscrição de um novo conjunto de relações sociais e espaciais com a produção de imaginários culturais:

\begin{abstract}
Em configurações como essas, a violência constitui a forma original do direito, e a exceção proporciona a estrutura da soberania. A "ocupação colonial" em si era uma questão de apreensão, demarcação e afirmação do controle físico e geográfico - inscrever sobre o terreno um novo conjunto de relações sociais e espaciais. Essa inscrição (territorialização) foi, enfim, equivalente à produção de fronteiras e hierarquias, zonas e enclaves; a subversão dos regimes de propriedade existentes; a classificação das pessoas de acordo com diferentes categorias; extração de recursos; e, finalmente, a produção de uma ampla reserva de imaginários culturais. (...) O espaço era, portanto, a matéria-prima da soberania e da violência que sustentava. Soberania significa ocupação, e ocupação significa relegar o colonizado em uma terceira zona, entre o status de sujeito e objeto (MBEMBE, 2016, p. 135).
\end{abstract}

No Brasil, aquela "forma original do direito" a que se refere Mbembe define a legislação colonial, caracterizada pela contradição sobre a vida e a morte dos índios. Ao analisar as "primeiras disposições do governo português com relação aos indígenas", o antropólogo brasileiro Julio Cezar Melatti (2014, p. 249) constata que "em tal regimento se dizia que a conversão dos indígenas é que constituía o motivo do povoamento do Brasil". No entanto, o mesmo documento, continua Melatti, "permitia que se combatessem os índios que agiam como inimigos, que fossem mortos ou feitos prisioneiros":

Seria um nunca acabar enumerar e indicar o conteúdo de todas as leis que se promulgaram a respeito dos indígenas durante o período colonial. Uma contradiz a outra e, mesmo aquelas que concedem liberdade aos índios, sempre apresentam alguma ressalva que permite cerceá-la de algum modo (MELATTI, 2014, p. 249-250).

O exercício dessa "violência do estado de exceção" que, como nota Mbembe, "opera a serviço da 'civilização'”, desde o período colonial, quando "o esbulho de suas terras e o apresamento de suas pessoas não raro se fez em ações bélicas permitidas pelo governo metropolitano e até com a utilização de suas tropas" (MELATTI, p. 241), depende da produção dos "imaginários culturais" de que trata Mbembe, os quais relegaram os indígenas a uma condição permanente de objeto. Nesse sentido, Vecchi (2007, p. 
181-182) observa que as ordens material e simbólica "são feitas coincidir ao máximo e antes das transformações disciplinares do corpo e regulamentares das populações (...) mostrando uma consciência adequada do uso da tecnologia simbólica sobre a qual fundamentar o poder sobre a vida":

\begin{abstract}
Portanto, questionar esses mecanismos de poder, para nós hoje significa basicamente questionar o conceito de representação e suas ambivalências constitutivas, de acordo com as quais, como nos mostra hoje a reflexão crítica sobre a representação, pode ocorrer que a forma seja trocada pelo conteúdo, que o significante (palavras, ações, imagens) possa ser confundido ou abertamente identificado com o significado (VECCHI, 2007, p. 182).
\end{abstract}

Pouco depois das epopeias coloniais O Uraguai, de Basílio da Gama, de 1769, e Caramuru, de Santa Rita Durão, de 1781, exaltadas pelo Romantismo pela representação de povos indígenas brasileiros, a literatura brasileira, nos versos do poema Ode ao homem selvagem, de Sousa Caldas, de 1785 , colocava em suspeita a separação entre selvagem e civilizado ${ }^{1}$ que primeiro legitimou e justificou a violência contra os povos indígenas, a sua exploração e a da terra:

O homem, que Fizeste? tudo brada;

Tua antiga grandeza

De todo se eclipsou; a paz dourada,

A liberdade com ferros se vê presa,

E a pálida tristeza

Em teu rosto esparzida desfigura

Do Deus, que te criou, a imagem pura.

(CALDAS, 1820, p. 125).

denuncia a primeira estrofe do poema, indicando a deterioração da imagem do "homem", a qual contrasta, a seguir, com a descrição do "homem selvagem" como uma "imagem de esplendor", influenciada, certamente, pelo mito do bom selvagem e pelo olhar europeu da natureza americana, concebida como natureza natural:

1 E por isso Gonçalves de Magalhães não o perdoa, escrevendo em seu prefácio a Suspiros poéticos e saudades que "Caldas, o primeiro dos nossos líricos (...) causa mesmo dó que cantasse o homem selvagem de preferência ao homem civilizado, como se aquele a este superasse, como se a civilização não fosse obra de Deus, a que era o homem chamado pela força da inteligência com que a Providência dos mais seres o distinguira!" (MAGALHÃES, 1859, p. 13). 
Que augusta imagem de esplendor subido

Ante mim se figura!

$\mathrm{Nu}$; mas de graça e de valor vestido

O homem natural não teme a dura

Feia mão da Ventura!

No rosto a Liberdade traz pintada

De seus sérios prazeres rodeada.

(CALDAS, 1820, p. 128).

$\mathrm{E}$, adiante, o poema questiona a quem pertence a razão, se ao selvagem ou ao suposto civilizado:

Ó Razão, onde habitas? ... na morada

Do crime furiosa,

Polida, mas cruel, paramentada

Com as roupas do Vicio; ou na ditosa

Cabana virtuosa

Do selvagem grosseiro? ... Dize ... aonde?

Eu te chamo, ó filósofo! responde.

(CALDAS, 1820, p. 129).

A pergunta, evidentemente, é retórica, como o comprova o epodo final da ode, que reclama a perda das virtudes teoricamente naturais para os vícios, enaltecidos, inclusive, como sugere o poema, por uma poesia que canta os valores da chamada civilização:

Cobriram-se as Virtudes

Com as vestes da Noite; e o lindo canto

Das Musas se trocou em triste pranto.

E desde então só rudes

Engenhos cantam o feliz malvado,

Que nos roubou o primitivo estado.

(CALDAS, 1820, p. 131).

A esses valores, o poeta indianista, autor do canto da morte de I-Juca Pirama, nomeou: "- Chame-lhe progresso / Quem do extermínio secular se ufana", escreve Gonçalves Dias (1956, p. 43-44), em Os timbiras. E continua:

Eu modesto cantor do povo extinto

Chorarei nos vastíssimos sepulcros,

Que vão do mar ao Andes, e do Prata

Ao largo e doce mar das Amazonas. 
sentarei meditabundo

Em sítio, onde não ouçam meus ouvidos

Os sons frequentes d'europeus machados

Por mãos de escravos Afros manejados...

Com efeito, o índio, pertencendo a um povo que se dizia prestes a ser extinto, simbolizou o desamparo humano diante da marcha do progresso material. O poema de Sousa Caldas se inscreve, assim, na noção de regeneração que surge no final do setecentos como um projeto espiritual e intelectual em contraposição ao materialismo da cultura europeia. Como constata Said (2007, p. 168), o que importa na noção de regeneração não são tanto os povos selvagens quanto o seu uso para a Europa moderna, como uma sorte de redenção ocidental que devolveria para a Europa um sentido da missão sagrada que teria se perdido: a "antiga grandeza" que "de todo se eclipsou", desfigurando "do Deus, que te criou, a imagem pura" (CALDAS, 1820, p. 125), e "que nos roubou o primitivo estado" (CALDAS, 1820, p. 131).

Aqui, no Brasil, a aparente exaltação dos povos indígenas em conflito com os colonizadores portugueses, promovida pelo Romantismo, em um momento de afirmação nacional e construção da identidade brasileira, esconde, no entanto, a extinção dos povos indígenas como condição do nascimento da nação, tal como alegorizado pela personagem Iracema, de

Figura 13

Antônio Parreiras.

Iracema, 1909.

Óleo sobre tela,

$60.5 \times 93 \mathrm{~cm}$. Fon-

te: https://masp.

org.br/acervo/

obra/iracema

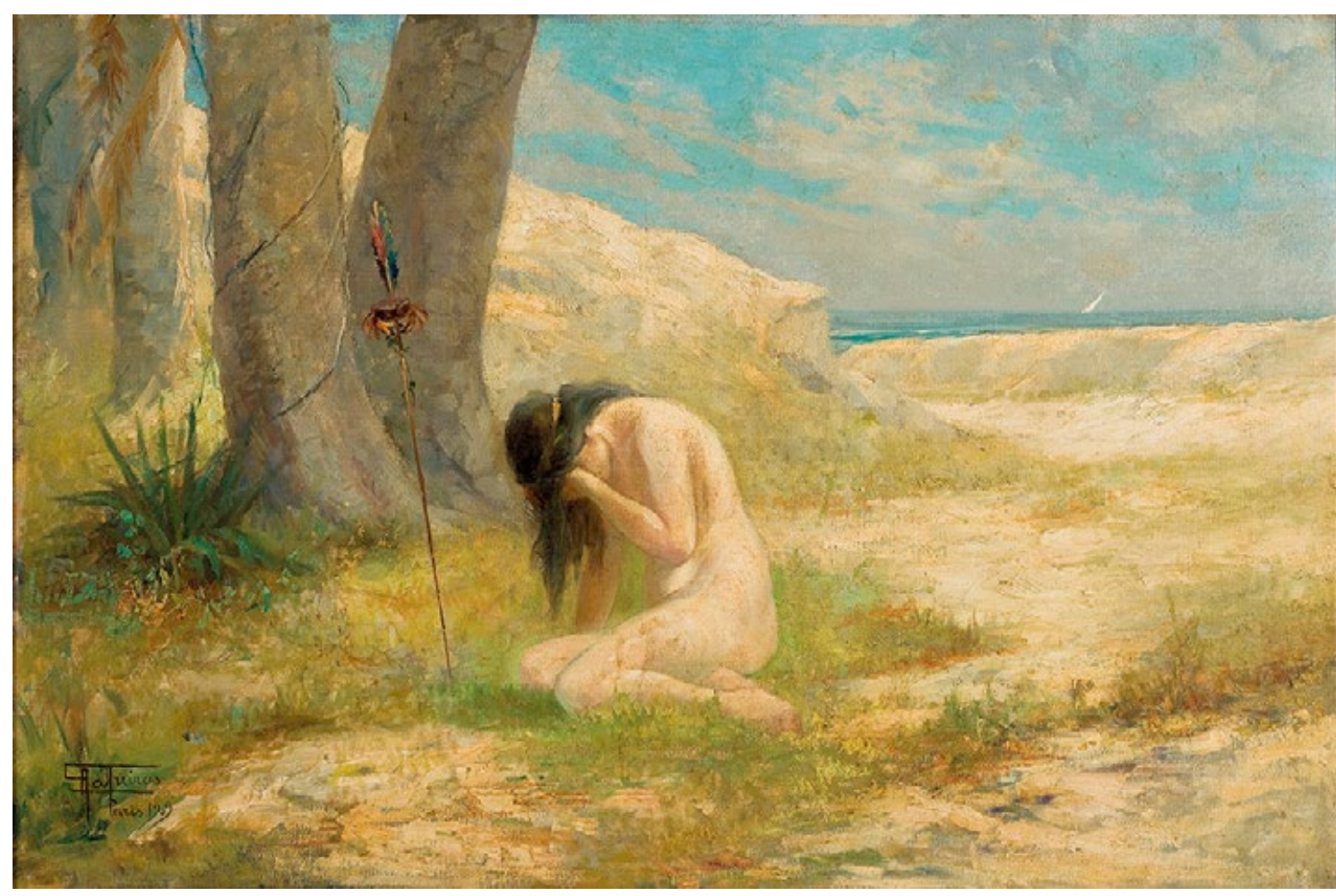


José de Alencar, que, como nota Doris Sommer (2004), professora de Literatura de Harvard, morre em nome do nascimento do brasileiro. Como um elemento, portanto, do passado, eliminado seja culturalmente, pela conversão ao cristianismo e ao capitalismo, seja fisicamente, de modo que seu "canto de morte" se fez ouvir tanto quanto ver:

Como, de fato, podemos ver em Iracema, de Antonio Parreiras, de 1909, que representa a personagem Iracema, que, alegorizando o processo de colonização do Brasil, morre depois do nascimento de Moacir, fruto de sua relação com o colonizador Martim, de Portugal.

Figura 14 Victor Meirelles. Moema, 1866. Óleo sobre tela, $130 \times 196.5 \mathrm{~cm}$. Fonte: https:// masp.org.br/acervo/obra/moema

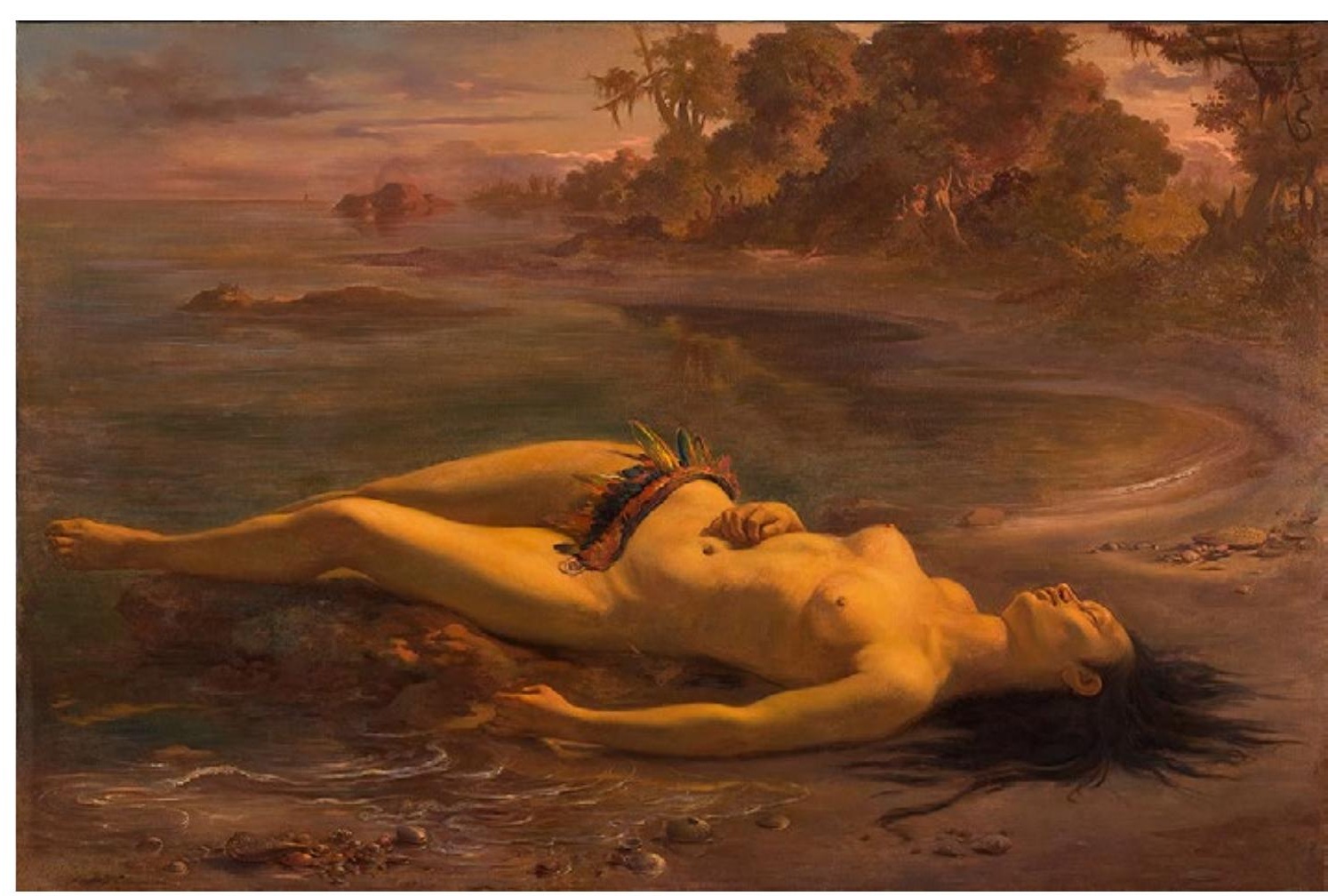

E em Moema, de Victor Meirelles, de 1866, que representa a personagem Moema, amante de Caramuru, do poema de Santa Rita Durão. E ainda em A Confederação dos Tamoios: Exéquias de Comorim, de Antônio Firmino de Monteiro, de 1879, que representa o funeral de Comorim, narrado no poema $A$ confederação dos tamoios, de Gonçalves de Magalhães:

Por sua vez, Lindóia, de José Maria de Medeiros, de 1882, representa a morte da personagem Lindóia, que se deixa picar por uma serpente no poema O Uraguai, de Basílio da Gama: 
Figura 15

Antônio Firmino de Monteiro. A confederação dos tamoios: exéquias de Camorim, 1879.

Óleo sobre tela, $100 \times 157 \mathrm{~cm}$.

Fonte: http:// enciclopedia. itaucultural.org.br

Figura 16 José Maria de Medeiros. Lindóia, 1882. Óleo sobre tela, 54,5 $x 81,5 \mathrm{~cm}$. Fonte: https://pt.wikipedia.org
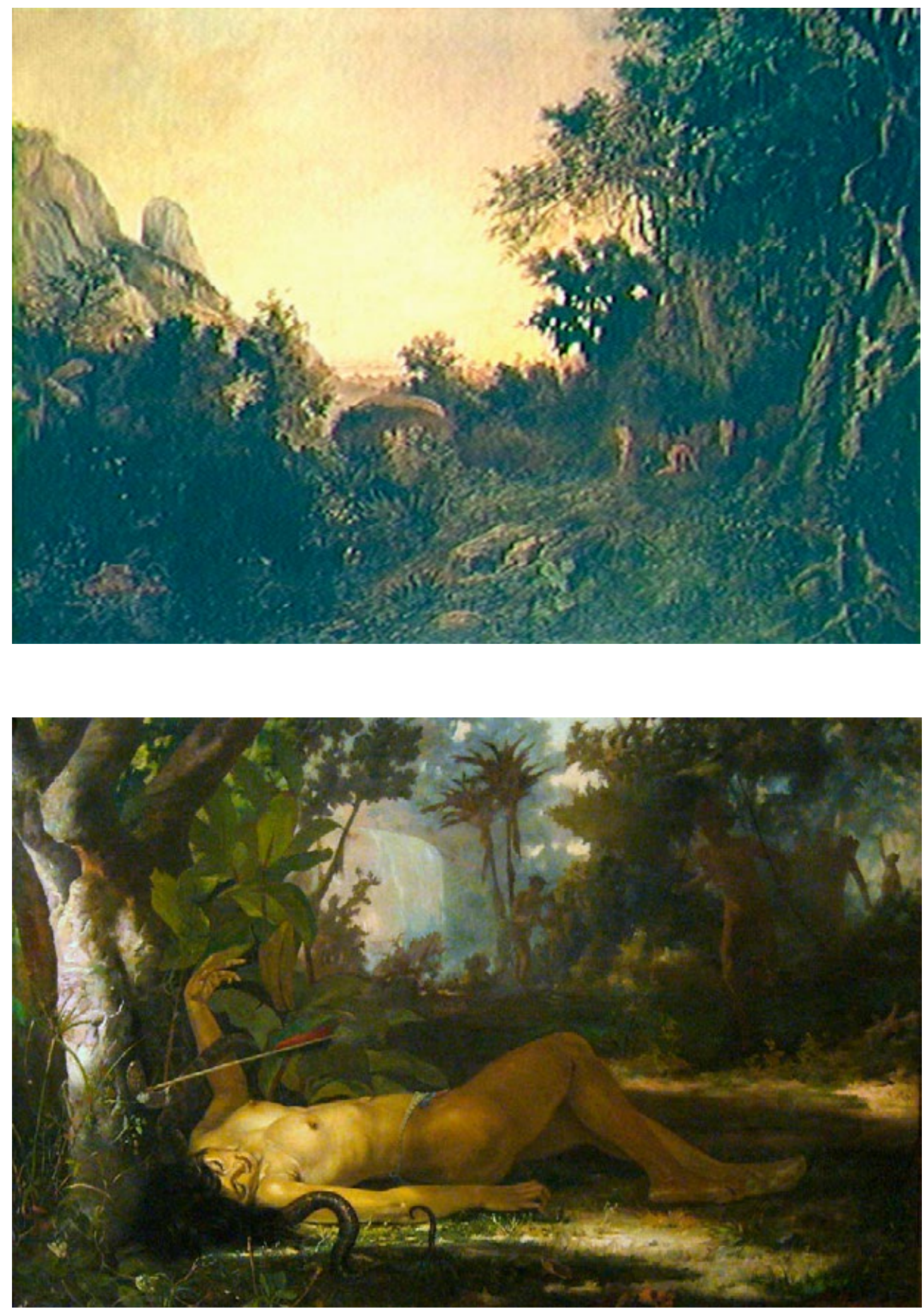

E por fim, O último tamoyo, de Rodolpho Amoedo, de 1883, representa a morte de Aimbiré, representante da aliança entre os povos tupinambá, guaianazes e aimorés, que, no poema Confederação dos Tamoios, de Gonçalves de Magalhães (1857, p. 322-323), brada: 
Tamoyo sou, Tamoyo morrer quero,

E livre morrerei. Comigo morra

O ultimo Tamoyo; e nenhum fique

Para escravo do Luso: a nenhum deles

Darei a gloria de tirar-me a vida.

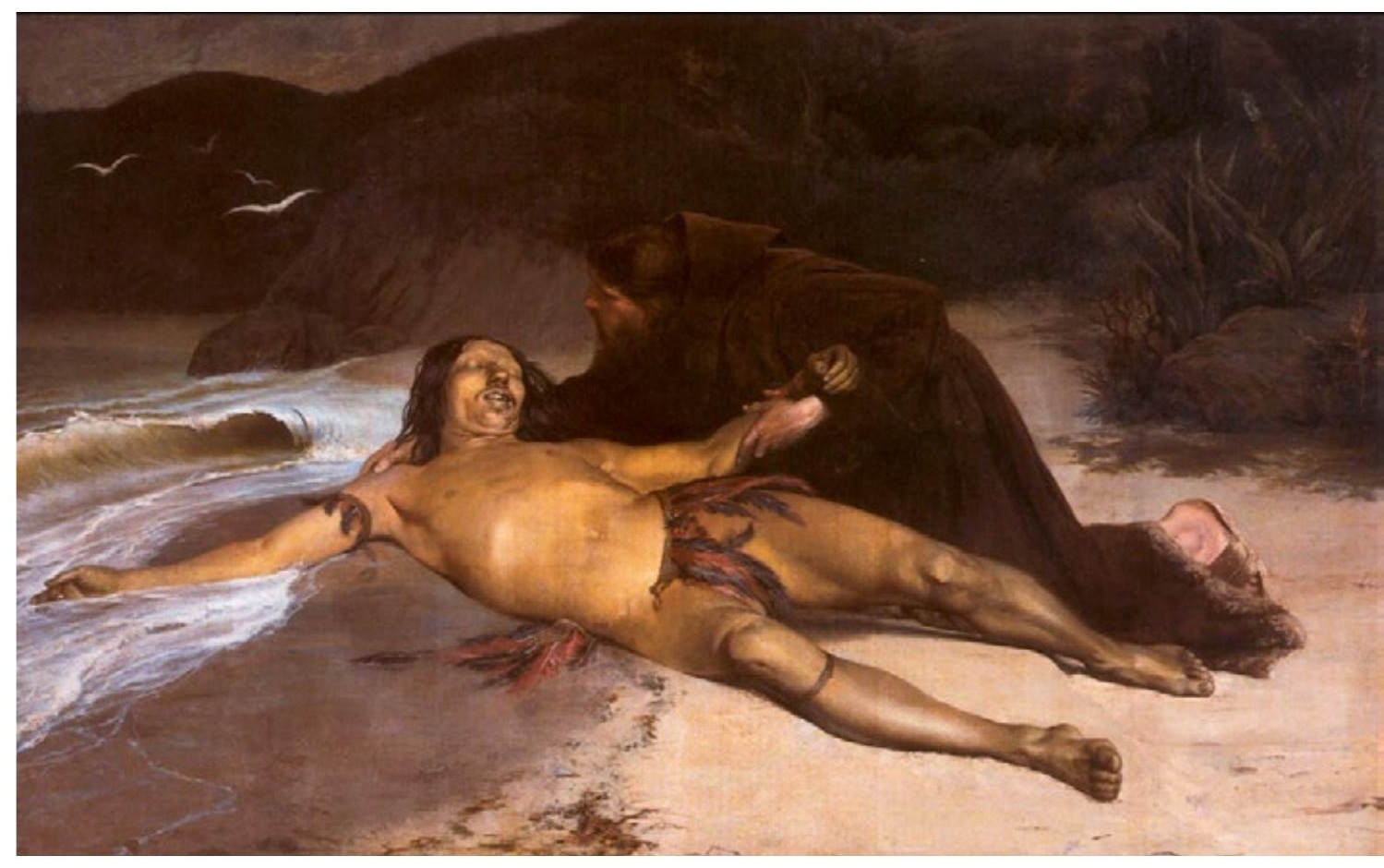

Concluo confirmando o que todos podemos ver: as pinturas todas retratam, figuradamente e literalmente, a "vida nua", aquela que, como definiu Agamben (2002, p. 189), qualquer um pode tirar "sem cometer homicídio", estando "reduzida a uma vida nua despojada de todo direito". Mais do que a vida natural, regida pelas normas da natureza e dos instintos animais, ou a natureza natural que, conforme Perrone-Moisés (2007, p. 42), o olhar europeu conferiu à natureza americana, desprovendo-a, assim, da cultura e da civilização, o que os índios representam, nessas telas, é a vida considerada "indigna de ser vivida", que corresponde, segundo Agamben (2002, p. 146), "à vida nua do homo sacer". "Aquele que é digno de ser morto", conforme Thiago Martins intitula uma de suas telas. E nesse sentido, a despeito da conhecida idealização pelo indianismo, e consoante o interesse de Said (2007, p. 51) pela exterioridade, evidenciando a representação - principal produto da exterioridade - como representação, as imagens são precisas. Afinal, o que resta documentado da representação indígena, é, como constata o professor de Literatura Brasileira Alcmeno 
Bastos (2011, p. 19), “mais uma 'visão sobre o objeto' do que o objeto, que, assim, 'serve como registro verdadeiro das imagens que dele foram produzidas ao longo dos tempos'”. "Em linhas gerais", conclui Bastos (2011, p. 20), "a representação literária do índio na literatura brasileira tem estado sincronizada com a representação que a sociedade brasileira vem dele fazendo ao longo dos tempos".

A obra de Thiago Martins, sobretudo em Necrobrasiliana, problematiza, enquanto mecanismos de poder, precisamente tais representações, sobre as quais se fundamenta, como constata Vecchi (2007, p. 182), "o poder sobre a vida", permanecendo invariavelmente associadas com a morte, cuja reprodução deliberada deve ser compreendida em sua relação com o colonialismo e o capitalismo.

\section{Referências}

AGAMBEN, Giorgio. Estado de exceção. Trad. Iraci D. Poleti. São Paulo: Boitempo, 2004.

. Homo sacer: o poder soberano e a vida nua I. Trad. Henrique Burigo. Belo Horizonte: UFMG, 2002.

BASTOS, Alcmeno. $O$ índio antes do indianismo. Rio de Janeiro: 7Letras: FAPERJ, 2011.

BENJAMIN, Walter. Sobre o conceito de história. In: . Magia e técnica, arte e política. Trad. Sérgio Paulo Rouanet. 7. ed. São Paulo: Brasiliense, 1994.

BUENO, Eduardo. Náufragos, traficantes e degredados: as primeiras expedições ao Brasil. Rio de Janeiro: Estação Brasil, 2016.

CALDAS, Antônio Pereira de Sousa. Obras poéticas do Reverendo Antônio Pereira de Sousa Caldas. Paris: Oficina de P. N. Rougeron, 1820.

DIAS, Gonçalves. I-Juca Pirama. In: TEIXEIRA, Ivan (org). Épicos. São Paulo: Editora da USP; Imprensa Oficial do Estado de São Paulo, 2008.

. Os timbiras: poema americano. Salvador: Progresso, 1956.

FANON, Frantz. Os condenados da terra. Rio de Janeiro: Civilização Brasileira, 1968.

FOUCAULT, Michel. Em defesa da sociedade: curso no Collège de France (1975-1976). São Paulo: Martins Fontes, 2005. 
LÉRY, Jean de. Histoire d'un Voyage faict en la terre du Brésil. Paris: Alpholse Lemerre, 1880. t. 2.

MAGALHÃES, Domingos José Gonçalves de. A confederação dos tamoyos. Rio de Janeiro: Dous de Dezembro, 1857.

. Suspiros poéticos e saudades. 2. ed. Paris: Morizot, 1859.

MBEMBE, Achille. Necropolítica. Arte e ensaios: revista do PPGAV/EBA/ UFRJ, Rio de Janeiro, n. 32, p. 123-151, dez. 2016.

MELATTI, Julio Cezar. Índios do Brasil. 9. ed. São Paulo: Editora da USP, 2014.

PERRONE-MOISÉS, Leyla. Vira e mexe, nacionalismo: paradoxos do nacionalismo literário. São Paulo: Companhia das Letras, 2007.

SAID, Edward W. Orientalismo: o Oriente como invenção do Ocidente. São Paulo: Companhia das Letras, 2007.

SOMMER, Doris. Ficções de fundação. Belo Horizonte: Ed. UFMG, 2004.

SOUTO, Alanna. Os indígenas na cartografia da América lusitana. Bol. Museu Paraense Emílio Goeldi. Ciências Humanas, Belém v. 12, n. 3, p. 817-837, set.-dez. 2017.

STADEN, Hans. Viagem ao Brasil. Rio de Janeiro: Officina Industrial Graphica, 1930.

VECCHI, Roberto. Império português e biopolítica: uma modernidade precoce? In: MEDEIROS, Paulo de. Postcolonial Theory and Lusophone Literatures. Portuguese Studies Center, Opleiding Portugese Taal en Cultuur, Faculteit Geesteswetenschappen, Universiteit Utrecht, 2007. 